\title{
CONSIDERATIONS REGARDING THE IMPACT OF LEGISLATIVE INFLATION ON ECONOMIC OPERATORS
}

Claudiu Ramon D. BUTCULESCU

Spiru Haret University, Bucharest

„Acad. Andrei Rădulescu” Legal Research Institute

\begin{abstract}
This paper addresses the impact of legislative inflation upon the activities of the commercial agents. A clear and transparent legal framework is required in order for the economic system to be efficient and to grow. Unfortunately, the large amount of norms that come into force monthly, if not weekly and regulate the activities of the moral persons, and in particular, the activities of the economic agents determine a high grade of informational entropy at a systemic level. This study tackles the possibility of improving the legal communication of norms by reducing legislative inflation. Firstly, the communication stream is analysed, and then the possibilities for improving such communication are brought forward.
\end{abstract}

Keywords: legislative inflation, legal communication, information entropy, economic agents, fiscal regulations

JEL Classification: $K 100, K 340, K 400$

\section{Introduction}

This paper covers the issue of legislative inflation. In the Romanian Legal System, as part of the Romanian Social Normative System, the need for clear regulations is high, seeing that Romania can be classified as a developing economy. For the past twenty-five years, multiple attempts have been made to transform the legal system into a coherent and transparent framework of law. The negative effects of legislative inflation are easy to observe within the Romanian economy. The vast multitude of laws and regulations that sometime address the same issue within social life only lead to confusion and ambiguity. The legal system must protect the bona fide economic agents, but also must prove itself nimble and flexible enough not to suffocate these agents, as the modern society is permanently changing, eliminating cultural and legal international barriers. (Ciongaru Emilian, 2012, p. 565) As the economic agents are the power that pushes forward the social system, the analysis of the negative effects of legislative inflation is certainly required. It may be that the inflation also produces a negative effect through poor legal communication, as the subjects of the law do not always understand properly the meaning of the laws. The laws themselves are sometimes unclear and ambiguous, adding to the uncertainty already in existence. The communication of law and the legislative inflation, as a problem in the 
development of the economic domain has not been thoroughly addressed in the specialized literature and even less with regard to the economic agents. The massive quantity of laws that are enforced every year determine a poor understanding and acceptance of the law generally, which leads in return, among other things, to evasion, pecuniary and even penal sanctions for the economic agents. The communication of law may be split into two categories: formal communication of law and material communication of law. The formal communication of law is the process of communicating provisions and regulations from the authorities to the subjects of law. It is the expression of the formal sources of law, which include mainly the laws, provisions and regulations. (Niemesch Mihail, 2014, p. 92) The material communication of law, on the other hand, may be defined as the process through which the society itself communicates its needs to the legislator, being external realities (Tutunaru Mircea, 2014, p. 401) and social needs, which the system of law converts into regulations and provisions. The formal communication of law is relevant from the perspective of legislative inflation, because in the relation between the material and formal sources of the law, the latter shall always be limited, while the former are practically limitless.

\section{Literature Review}

Within the specialized literature, the legislative inflation has been addressed. To this end, Professor Sofia Popescu showed that legislative inflation represents a potential danger to society (Sofia Popescu, 1998). The systemic approach to law and law as communication has also been studied in the specialized literature. As such, models of communication were developed by scholars of law. A relevant work in this field pertains to reputed scholar Jurgen Habermas. He underlined that there are three modes of communication: cognitive, interactive and expressive (Jurgen Habermas, 1979, p. 58). Also, he proposed a model of linguistic communication which shows that language may be considered as a medium for three interconnecting worlds seeing that every successful communication implies a tripartite relation between expression and a) the external world as a complex of factual status; b) own social order, as a whole of all interpersonal rules, regulated and considered legitimate in a given society and c) the internal world of the issuer as a complex of its internal experiences. (Jurgen Habermas, 1979, p. 66-67)

Another reputed scholar, Niklas Luhmann, believed that every communication process differentiates and synthesizes its own components, respectively information, expression and understanding. According to this scholar, these components must differentiate and synthesize simultaneously (Kathrin Maurer, 2010, p. 5). He considered that communication should not be understood as a process of transmission (Niklas Luhmann, 2012, p. 116), because symbolic systems like the system of law relate directly to the improbability of communication.

These elements acquire a punctual structure when they are coupled through a specific medium like law, theory et.al. In other words, law as a medium of communication represents a referential system in which all these elements, as 
shown above, namely information, expressions and understandings become meaningful. Following the same direction, Romanian doctrine discussed the notion of "given" in the process of constructing the law (Anita M. Naschitz, 1969, p. 85).

Luhmann showed that differentiation is an important element in the conceptualization of communication, especially in distinguishing between information (experience) and expression (action) (Niklas Luhmann, 2012, p. 200).

Another theory regarding communication from the perspective of law was developed by Mark van Hoecke, which shows that human action involves interpersonal relations and by that communication. As such, law offers both a referential framework for human action as well as for communication between people (Mark van Hoecke, 2002, p. 7). The same author considered that law is essentially based on communication: between legislator and citizens, between courts and parties, between legislative power and the judiciary power, between the parties of any contract etc.

Moreover, the aspect of law as communication implies a rational dialogue between the operators of law, as a final means of protection for the just interpretation of the law. Van Hoecke does not propose a new model of communication related to the system of law, but rather discusses a new approach of legal theory concepts, from a communicational view.

Both national law and European Law have a profound and stern impact on companies. As such, the danger and costs generated by legislative inflations could be better understood if we explain further the negative effect on companies. Legislative inflation appears as an undesired effect of legal communication. Legal communication could be envisioned as a stream of legal messages, emitted by the public authorities and having a mandatory effect for the subjects of law, including companies. The components of the legal message that overload the capacity of understanding of the receiver, that is the subject of law, give birth to legislative inflation. On the other hand, the companies themselves, as business organizations, are entities formed for the purpose of carrying on commercial enterprise. (Encyclopadia Britannica Online) Thus, they need coherent and transparent provisions by which they efficiently may conduct their businesses. Legislative inflation leads to legal uncertainty which will affect the activities of the aforementioned companies, having a direct negative effect on their development. However, legislative inflation, also has an indirect negative effect on the society itself. A healthy economic environment can only be maintained if the companies that sustain that environment are themselves efficient.

In the specialized literature, with regard to legislative inflation, significant answers may be given by behavioral economics, which allow us to analyze the way in which information is presented and perceived. This area of study incorporates insights from psychology and other social sciences. (Bernheim B. Douglas, Rangel Antonio, 2007) Also, behavioral economics considers that increasing the realism of psychological elements of economic analysis will improve the field of economics, generating theoretical insights, better economic predictions and better policies. (Camerer Colin D., Loewenstein George, 2004, p. 3) No doubt that behavioral 
economics could bring forth an entire new vision regarding the perception of legislative inflation by the economic agents.

\section{Theoretical Background}

From an economic perspective, inflation, in economics, is defined as collective increases in the supply of money, in money incomes or in prices (Encyclopædia Britannica Online). Within the system of law, legislative inflation may be defined as the increase of the quantity of law beyond the necessities of the system itself. In specialized literature, it has been shown that the causes of legislation are the same causes of legislative inflation. (Svein Eng, 2002) This paper aims to show that poor legal communication augments the negative effects of legislative inflation. The legal background regarding trading companies is composed of various regulations, of which some are drafted as laws, while others are emitted in the form of ordinances. Some of the most important regulations that govern the activities of companies in Romania are the Law no. 31/1990 regarding companies, the Fiscal Code, the Fiscal Procedure Code and the Civil Code.

\section{Legislative inflation from the perspective of Law no. 31/1990 regarding companies}

The principal law that regulates the activities of trading companies is Law no. 31/1990 regarding companies. While in the past, its title mentioned trading companies, with the adoption of the actual Civil Code, the term "commercial" and other similar notions were removed and all commercial relations became civil relations, while the term "trading company" was change for "professional" or simply "company". In addition to the above mentioned law, there are other sources of law that regulate this field.

Since its inception, the Law no. 31/1990 has suffered numerous changes and modifications. Thus, the abovementioned law was modified for 35 times since its entry into force, in the year 1990, which shows us that on average, this law was modified once every eight months. In fact, almost every year, the law was modified at least once, with a hiatus of three years, between 1994-1996 and also in 2014. The activity of companies must rely on a stable and predictable environment, both economic and legal. If the legal framework fluctuates so dramatically, it leads to informational entropy, thus to uncertainty. As such, an uncertain environment leads also to less productive activities for the companies, who permanently need to adapt to the new legislative modifications. The high frequency of changes in the law is also a form of legislative inflation, because the enormous amount of information that must be assimilated by companies directly affects their productivity, their profits and indirectly, the economic growth. Besides the Law no. 31/1990, more than 400 laws regulate commercial activities in Romania, which of course can only increase the amount of informational entropy within the economic system. Also, the legislation inflation in this area is growing, as shown below (number of modifications each year): 


\section{Modifications made to Law no. 31/1990 2014)}

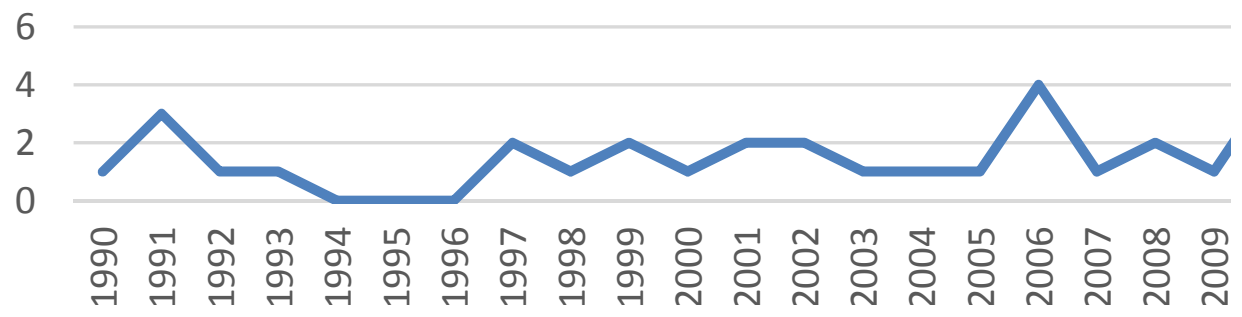

Thankfully, the last year no modifications were brought to the law, which contributed to a more predictable and stable legal framework. Even if these modifications are necessary, the law should be modified at longer intervals, to allow companies to adapt themselves to the new modifications. The legislative inflation also determines a poor communication of legal rules which adds to the already existent informational entropy. The managers and operators of Romanian companies must understand and comply with the legal rules newly introduced. Firstly, the rules must be understood, but for them to be understood, those rules must be clear and simple and as few as possible. A complicated framework increases the vulnerability of the companies in front of the authorities, which themselves become, at some points, entangled in these numerous and ambiguous rules. More important, many of these modifications did not have even the desired effect, as companies adapted themselves to elude such provisions. For example, the Emergency Ordinance no. 54/2010 stated that no transmission of share from a shareholder to a newcomer into the society can be made, before publication of the shareholders decision in the Romanian Official Journal. Also, for the cession to operate, a period of 30 days since publication must pass, without any creditor opposing the cession. Needless to say, workarounds for this issue were found and the provision itself nowadays does not constitute an absolute impediment to a possible cession. In other cases, the legislative inflation leads to cumbersome procedures that are difficult to follow by the companies. For example, if a person wants to found a new company, it has to complete a rather large file, being some time at the mercy of complete strangers. For example, the founder of a company needs to obtain the written consent of the blockhouse association where he wants to establish his official headquarters, as well as the written consent of the adjacent neighbours (the ones that have common walls with the space were the headquarter is located). All these provisions provide for uncertainty in the legal framework. The need for a certainty within a legal system is obvious, and legal certainty implies that a person knows or at least has the possibility of knowing the legal consequences when breaking the law (Alexandru Măgureanu, 2014, p. 275). The problem within legislative inflation is that there are so many norms, of which some regulate roughly the same area that both the natural and the moral persons may not 
accurately know that they are breaking the law. In a system with a high rate of legislative inflation, there is a strong possibility that mandatory provisions may not be justly upheld. Even more serious is the problem of rules that regulate the same field. Not only they don't serve the purpose for which they were drafted, but they also negatively affect the activity of all subjects of law, including companies, both directly and indirectly.

\section{Fiscal legislative inflation}

Fiscal regulations are essential for the proper development of the economy. However, in this legal area, the things are even more complicated. The Fiscal code and the Fiscal procedure code suffered far more modifications than Law no. 31/1990. As a matter a fact, the Fiscal code was modified 312 times, through other laws, ordinances or similar regulations, since its adoption, in 2003. That measures up to approximately one modification every month, which of course means a huge amount of provisions. Such a legislative inflation can only lead to serious repercussions on the companies, as the fiscal rules are almost entirely mandatory for all persons and failure to abide by them is drastically sanctioned. The number of modifications to the Fiscal code may be found within the following chart:

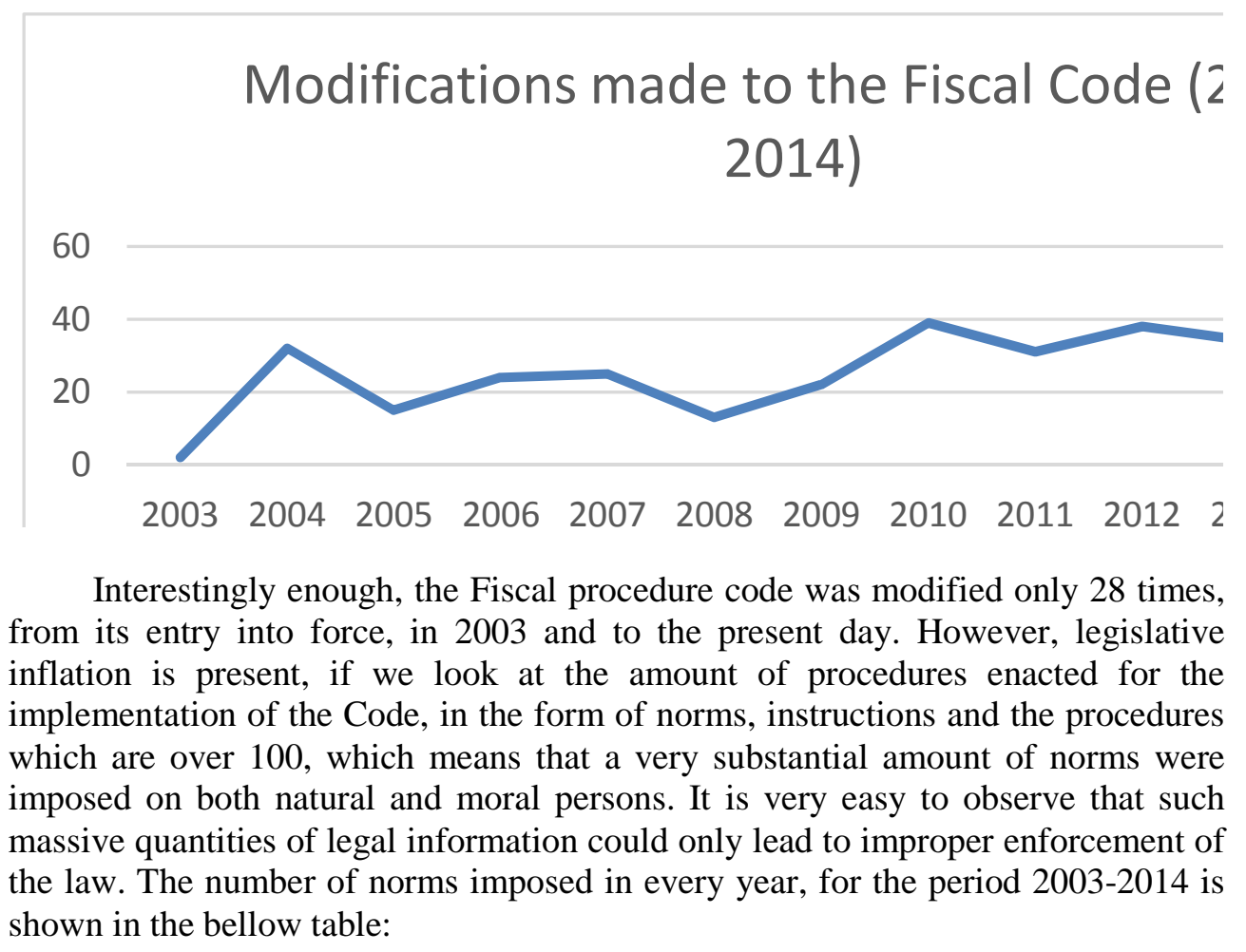




\section{Procedures adopted for the implemental the Fiscal Procedure Code (2003-201}

20

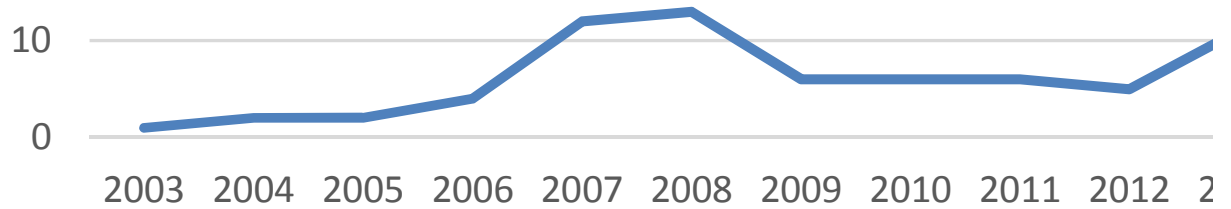

As it may be observed, the legislative inflation in the fiscal area is quite high, and this produces negative effects for the companies who may find themselves lost in this ocean of regulations and for the state, as the amount of taxes is reduced by tax evasion. Again, there is a need for clear regulations and transparent provisions and all modifications should be made only when a reasonable period of time has passed, in order to allow companies to get accustomed to the new regulations.

From a comparative point of view, legislative inflation is an isolated issue specific only to the Romanian system of law. For example, in France, there were more the 10.000 pages of the Official Journal that were printed, between $1^{\text {st }}$ of January 2014 and 30rd of June, the same year. (www.lemonde.fr) Also, in the doctrine it has been shown that normative complexity costs France 60 billion of euro annually, according to the OECD. (Duţu Mircea, 2015, p. 254) This shows, without any doubt that legislative inflation is a recurring problem in other countries as well. In the United States, the number of regulations rose from three volumes, containing 2.599 pages in 1936 to 36.487 pages in 1978, as it was measured by Milton Friedman. (Friedman Milton, Friedman Rose, 1979, p. 190-191) Although we have no concrete data at this moment on how the legislative inflation affects the activity of the companies and cannot give a specific number regarding costs and supplemental expenses made for the attenuation of legislative inflation, seeing that in France generates expenses of 60 billion euro annually, it is reasonable to believe that in a country with a more young and less developed legal framework, legislative inflation could produce significant economic damages. A further step in this field of research would be to continue and evolve from the theoretical premises included in this paper to a more empirical approach. Although at this moment there are no factual data regarding the losses that companies suffer as a negative effect of legislative inflation, through field research instruments such as interviews and surveys which will hopefully bring to light more information on the economic losses. 


\section{Conclusions}

In conclusion, the legislative inflation negatively affects the activities of the companies, both directly and indirectly. Of course, due to the dynamic evolution of the economic system and of the market itself, such inflation cannot be eliminated, but can be successfully alleviated, by drafting predictable and clear norms, which should enter into force after a reasonable period of time since the adoption of the law or since the previous modification of the law. If the laws that regulate the activity of companies would be drafted clearly and transparently, without ambiguous notions and will be limited to a certain amount of essential regulations, thus reducing legislative inflation, Romanian companies will be able to allocate more resources to their own development, instead of wasting such resource on attempts to clarify and interpret the law. Also, we believe that the public authorities should take into consideration, when elaborating and enforcing the regulations, the following aspects: a) creating means and instruments of control over the numbers of new regulations and provisions; b) preemptive evaluation of the impact of regulations and norms; c) periodical revision of the efficiency of norms and regulations; d) reducing and simplifying the regulations and provisions destined for SME (small and medium enterprises); e) improvement of the enforcement of legal measures, both by accurate and transparent information and by providing effective means of assistance for the enterprises; f) reduction of expenses for the implementation of European Union Regulations, Directives et.al. It is also important to consider attracting the participation of the general public to the legislative process, by publicly consulting the subjects of law before enacting and enforcing regulations that may affect their activities. It is also important to evolve, in the process of the participation of general public to the legislative process, from simple and passive public consultation, where state authorities just post on the web sites projects of regulations to effective consultations with the professional bodies and companies representative. To the same end, the communication between the Parliament and the subjects of law, in our case, the companies should improve, as to the practical effects of the laws that are drafted and later enforced. The approach of this paper represents only the beginning of a larger research, which will also try in later works, to assess economically and financially the effects of legislative inflation on companies, and as such, to provide better means and solutions for this problem.

This paper has been financially supported within the project entitled "Horizon 2020 - Doctoral and Postdoctoral Studies: Promoting the National Interest through Excellence, Competitiveness and Responsibility in the Field of Romanian Fundamental and Applied Scientific Research", contract number POSDRU/159/1.5/S/140106. This project is co-financed by European

Social Fund through Sectoral Operational Programme for Human Resources Development 2007-2013. Investing in people! 


\section{References}

Bernheim B. Douglas, Rangel Antonio (2007), Behavioral Public Economics: Welfare and Policy Analysis with Nonstandard Decision-Makers, in ed. Peter Diamond, Hannu Vartianinen, Behavioral Economics and Its Applications, Princeton: Princeton University Press.

Camerer Colin D., Loewenstein George (2004), Behavioral Economics: Past, Present, Future, in ed. Colin F. Camerer, George Loewenstein, Matthew Rabin, Advances in Bahavioral Economic, Princeton: Princeton University Press.

Ciongaru Emilian (2012), Receptarea jurisprudenţei Curţii de Justiţie a Uniunii Europene în procesul de codificare din statele membre, în Ştiinţă şi Codificare în România, Bucharest: Universul Juridic Publishing House.

Duţu Mircea (2015), Dreptul: între ipostaze teoretice şi avatarurile modernizării, Bucharest: Universul Juridic Publishing Press.

Eng Svein (2002), Legislative Inflation and the Quality of Law, in ed. Luc Wintgens, Legisprudence: A New Theoretical Approach to Legislation, Oregon: Bloomsbury Publishing.

Friedman Milton, Friedman Rose (1979), Free to choose. A personal statement, New York: Harcourt Inc.

Habermas Jurgen (1979), Communication and the Evolution of Society, trans. Thomas McCarthy, Boston: Beacon Press.

van Hoecke Mark (2002), Law as communication, Oregon: Hart Publishing.

Luhmann Niklas (2012), Theory of Society, trans. Rhodes Barrett, vol. 1, Stanford: Stanford University Press.

Maurer Kathrin (2010), Communication and Language in Niklas Luhmann's SystemsTheory, Pandemonium germanicum, 16: 1-21.

Măgureanu Alexandru (2014), Legal certainty and legitimate expectations, in The Proceedings of the International Conference Communication, Context and Interdisciplinarity, Târgu-Mureş: „Petru Maior” University Press.

Naschitz Anita M. (1969), Teorie şi tehnică în procesul de creare a statului şi dreptului, Bucharest: Romanian Academy Publishing House.

Niemesch Mihail (2014), Teoria generală a dreptului, Bucureşti: Hamangiu Publishing House.

Popa Nicolae (2008), Teoria generală a dreptului, $3^{\text {rd }}$ Edition, Bucharest: C.H. Beck Publishing House.

Popescu Sofia (1998), Statul de drept în dezbaterile contemporane, Bucharest: Romanian Academy Publishing House.

Teubner Gunther (1987), Introduction to Autopoietic Law, in Autopoietic Law: A New Approach to Law and Society, Berlin: de Gruyter.

Tutunaru Mircea (2014), Study on Real and Formal Sources of Law, in Challenges of the Knowledge Society, Bucharest: Nicolae Titulescu Publishing House.

Encyclopædia Britannica Online, s. v. "inflation", accessed iunie 11, 2015, http://www.britannica.com /EBchecked/topic/287700/inflation.

Encyclopædia Britannica Online, s. v. "business organization", accessed iulie 05, 2015, http://www.britannica.com/topic/business-organization/The-impact-of-the-largecompany.

http://www.lemonde.fr/les-decodeurs/breve/2015/01/26/l-inflation-legislative-depuis-40ans-resumee-en-un-graphique_4563734_4355770.html, accessed iunie 11, 2015. 
